\title{
A Labile Component of AMPA Receptor-Mediated Synaptic Transmission Is Dependent on Microtubule Motors, Actin, and $\mathrm{N}$-Ethylmaleimide-Sensitive Factor
}

\author{
Chong-Hyun Kim and John E. Lisman \\ Department of Biology, Brandeis University, Waltham, Massachusetts 02454
}

\begin{abstract}
Glutamate receptor channels are synthesized in the cell body, are inserted into intracellular vesicles, and move to dendrites where they become incorporated into synapses. Dendrites contain abundant microtubules that have been implicated in the vesicle-mediated transport of ion channels. We have examined how the inhibition of microtubule motors affects synaptic transmission. Monoclonal antibodies that inactivate the function of dynein or kinesin were introduced into hippocampal CA1 pyramidal cells through a patch pipette. Both antibodies substantially reduced the AMPA receptor-mediated responses within 1 hr but had no effect on the NMDA receptor-mediated response. Heat-inactivated antibody or control antibodies had a much smaller effect. A component of transmission appeared to be resistant even to the combination of these inhibitors, and we therefore explored whether other agents also produce only a partial inhibition of transmission. A similar resistant component
\end{abstract}

was found by using an actin inhibitor (phalloidin) or an inhibitor of NSF ( $\mathrm{N}$-ethylmaleimide-sensitive fusion protein)/GluR2 interaction. We then examined whether these effects were independent or occluded each other. We found that a combination of phalloidin and NSF/GluR2 inhibitor reduced the response to $\sim 30 \%$ of baseline level, an effect only slightly larger than that produced by each agent alone. The addition of microtubule motor inhibitors to this combination produced no further inhibition. We conclude that there are two components of AMPA receptor-mediated transmission; one is a labile pool sensitive to NSF/GluR2 inhibitors, actin inhibitors, and microtubule motor inhibitors. A second, nonlabile pool resembles NMDA receptor channels in being nearly insensitive to any of these agents on the hour time scale of our experiments.

Key words: microtubule; kinesin; dynein; NSF; actin filament; synaptic transmission
The mechanisms that regulate the function of glutamate receptors are not well understood. An emerging hypothesis is that the AMPA type of glutamate channels is in a dynamic state of turnover that involves vesicle fusion and retrieval processes (Kim and Huganir, 1999; Luscher et al., 2000; Turrigiano, 2000). Recent work has visualized the activity-dependent movement of intracellular green fluorescent protein-labeled (GFP) AMPA receptors directly from the dendrite to the spine (Shi et al., 1999). This movement requires the activation of NMDA receptor channels and thus may occur during the induction of long-term potentiation (LTP). Other recent work indicates that during LTP new channels are inserted into the synaptic membrane (Hayashi et al., 2000). Conversely, it appears that NMDA receptordependent long-term depression (LTD) is accompanied by a decrease in the number of synaptic AMPA receptor clusters (Carroll et al., 1999b). In addition to these activity-dependent processes there appears to be a constitutive process required to maintain AMPA receptor-mediated responses. The evidence for this is that agents that interfere with postsynaptic endocytosis and exocytosis processes affect basal synaptic transmission (Lledo et al., 1998; Song et al., 1998; Luscher et al., 1999; Noel et al., 1999).

Received Feb. 21, 2001; revised March 30, 2001; accepted April 5, 2001.

This work was supported by National Institutes of Health Grant 5 RO1 NS2733709. We gratefully acknowledge the support of the W. M. Keck Foundation. We thank Dr. Nikolai Otmakhov for discussions on these experiments and Dr. Richard Huganir for the NSF/GluR2 interaction inhibitory peptide.

Correspondence should be addressed to Dr. John E. Lisman, Department of Biology, Brandeis University, Waltham, MA 02454. E-mail: Lisman@brandeis.edu.

C.-H. Kim's present address: Department of Neuroscience, Johns Hopkins University School of Medicine, Baltimore, MD 21205.

Copyright (C) 2001 Society for Neuroscience $\quad 0270-6474 / 01 / 214188-07 \$ 15.00 / 0$
If AMPA channels are subject to a rapid turnover process, there must be processes that maintain the supply of AMPA channels. AMPA channels appear to be synthesized in the soma and thus must travel to dendrites to be incorporated into synapses (Eshhar et al., 1993) (for review, see Kelly and Grote, 1993; Petralia, 1997; Somogyi et al., 1998). Intracellular vesicular movement in the cytoplasm generally occurs via the action of cytoskeletal motor proteins (Goldstein and Yang, 2000). Microtubules are found along dendritic shafts and are not prominent in spines. In contrast, actin is concentrated strongly in spines. Studies in many cell types indicate that microtubule motor proteins play a role in the transport of vesicles from the Golgi apparatus to the cell periphery (Burkhardt, 1998; Hamm-Alvarez and Sheetz, 1998; Hirokawa, 1998; Hirokawa et al., 1998; Lippincott-Schwartz, 1998; Huang et al., 1999; Karki and Holzbaur, 1999; Kreitzer et al., 2000; Goldstein and Yang, 2000), where there is a transfer to actin-mediated transport near the plasma membrane (Shelanski et al., 1981; Gavin, 1997; Depina and Langford, 1999; Huang et al., 1999; Goode et al., 2000). Thus, based on studies in other cells types, it would be likely that microtubule motors mediate the movement of vesicles carrying AMPA channels from the cell body to distal dendrites.

Relatively little is known about the actual role of microtubules in dendrites and their function in maintaining synaptic transmission. Recently, it has been shown that the activity-dependent fusion of vesicles into the dendritic membrane is blocked by the depolymerization of microtubules (Maletic-Savatic and Malinow, 1998). However, it was not examined whether these processes affected AMPA channel function. Another recent study identified a kinesin microtubule motor that appears to be responsible 
for the dendritic transport of NMDA channels (Setou et al., 2000), but the role of this motor in the maintenance of synaptic transmission also was not examined. We therefore have undertaken to determine whether AMPA receptor-mediated or NMDA receptor-mediated transmission is affected by interfering with the function of microtubule motor proteins. In the course of this study it became clear that, although the inhibition of microtubule motors decreased AMPA receptor-mediated transmission, these agents produced only a partial inhibition of AMPA receptor-mediated transmission. Previous work with several other agents also provided evidence that only a component of transmission could be affected (Nishimune et al., 1998; Kim and Lisman, 1999). In the second part of this study we examined this question in more detail and established clear evidence for a resistant component. We also asked whether these different agents work on independent components of transmission or on a common component. Our results indicate that all agents work on a common labile pool and that there is a separate, nonlabile pool that is not affected by inhibitors of actin, NSF/GluR2 interaction, or microtubule motors.

\section{MATERIALS AND METHODS}

Slice preparation and solutions. Hippocampal slices $(400 \mu \mathrm{m})$ were prepared from 2- to 3-week-old Long-Evans rats. In brief, slices were allowed to recover for a minimum of $2 \mathrm{hr}$ on the surface of cell culture inserts in an incubation chamber to which humidified oxygen was supplied continuously $\left(\begin{array}{llll}95 \% & \mathrm{O}_{2} / 5 \% & \mathrm{CO}_{2}\end{array}\right)$ and then transferred to a submerged-type recording chamber with continuous flow $(2.3 \mathrm{ml} / \mathrm{min})$ of oxygenated artificial $\mathrm{CSF}(\mathrm{aCSF})$ at $35^{\circ} \mathrm{C}$. The aCSF for recording contained (in mM) $124 \mathrm{NaCl}, 26 \mathrm{NaHCO}_{3}, 1.25 \mathrm{NaH}_{2} \mathrm{PO}_{4}, 2.5 \mathrm{KCl}, 4$ $\mathrm{CaCl}_{2}, 4 \mathrm{MgSO}_{4}, 20$ D-glucose, and 0.05 picrotoxin. The whole-cell recording pipette was filled with (in $\mathrm{mM}$ ) $130 \mathrm{Cs}$-methanesulfonate, 10 CsCl, 10 HEPES, 4 Mg-ATP, $0.4 \mathrm{Na}_{3}$ GTP, 0.2 EGTA, and 10 phosphocreatine, $\mathrm{pH} 7.3, \sim 300 \mathrm{mOsm}$. In the whole-cell recording for the NMDA receptor-mediated EPSC measurement, $4 \mathrm{mM} \mathrm{Ca}^{2+}, 1 \mathrm{~mm}$ $\mathrm{Mg}^{2+}$, and $10 \mu \mathrm{M} \mathrm{CNQX}$ (6-cyano-7-nitroquinoxaline-2,3-dione) or $5 \mu \mathrm{M}$ NBQX (2,3-dioxo-6-nitro-1,2,3,4-tetrahydorbenso[f]quinoxaline-7-sulfonamide) were contained in aCSF.

Electrophysiology. In whole-cell experiments two synaptic pathways were stimulated alternately at $12 \mathrm{sec}$ intervals. Stimulation of two pathways of Schaffer/commissural afferents was performed with two glass electrodes filled with aCSF. The independence of the two synaptic pathways was tested by a paired-pulse protocol. Paired-pulse facilitation of EPSCs was observed only when two consecutive pulses with a $50 \mathrm{msec}$ interval were applied to the same path. When two consecutive pulses were applied to different pathways, no facilitation was observed, indicating that the two pathways do not have common axons. CA1 pyramidal neurons were identified visually by a modified infrared differential contrast method. Cells were held at $-65 \mathrm{mV}$ with an Axopatch 1D (Axon Instruments, Foster City, CA) amplifier. Series resistance (8-15 M $\Omega$ ) and input resistance (70-200 M $\Omega$ ) were monitored every $6 \mathrm{sec}$ by measuring the peak and steady-state currents in response to $2 \mathrm{mV}, 30$ msec hyperpolarizing voltage steps. Holding current also was monitored throughout the experiment. For monitoring the stability of the slice responsiveness, we recorded the amplitude of fEPSP simultaneously. Data were filtered at $1 \mathrm{kHz}$. Changing of the internal pipette solution was done as described previously (Otmakhov et al., 1997). Experiments with $>15 \mathrm{M} \Omega$ series resistances were discarded. Responses were averaged at 2 min intervals and then normalized to the average of the baseline recording before drug application. All data acquisition and analysis were done by custom software written in Axobasic 3.1. Mean \pm SEM was used for representing average values. Error bars in each graph indicate SEM. The data were compiled in Microsoft Excel and plotted with Microcal Origin. Data were fit (Microcal Origin) by using the Boltzmann equation:

$$
Y=A 2+(A 1-A 2) /\left(1+\exp \left(X-X_{0}\right) / d x\right)
$$

where $A 1$ is the initial value, $A 2$ is the final value, $X_{0}$ is the $x$ value (minute) at $Y_{50 \%}$, and $d x$ is the time constant (minutes); however, no importance should be attached to this particular fitting function.

Materials. The antibodies are from Sigma (St. Louis, MO): anti-kinesin antibody (monoclonal clone IBII, K1005), anti-dynein antibody (monoclonal clone 70.1, D5167), anti-digoxin antibody (monoclonal clone DI22, D8156), anti-biotin antibody (monoclonal clone BN-34, B7653), and anti-gastric mucin antibody (monoclonal clone 45M1, M5293). The final concentration of antibodies (Abs) was $100 \mu \mathrm{g} / \mathrm{ml}$. Repeated (10 times) heating $\left(75^{\circ} \mathrm{C}\right.$ for $\left.30 \mathrm{sec}\right)$ and cooling $\left(4^{\circ} \mathrm{C}\right.$ for $\left.1 \mathrm{~min}\right)$ were used for the inactivation of anti-kinesin antibody. The rat $N$-ethylmaleimide-sensitive fusion protein (NSF)/GluR2 interaction inhibitory peptide (NSF/GluR2 ip, KRMKVAKNPQ) was a gift from Dr. R. Huganir (Johns Hopkins University School of Medicine, Baltimore, MD). In peptide application experiments a cocktail of three protease inhibitory peptides, bestatin, leupeptin, and pepstatin (Boehringer Mannheim Biochemical, Indianapolis, IN), was added to the internal solution (100 $\mu \mathrm{M}$ each; Otmakhov et al., 1997). Phalloidin was obtained from Calbiochem (La Jolla, CA).

\section{RESULTS}

\section{A selective decrease in AMPA receptor-mediated currents by postsynaptic application of anti-dynein and anti-kinesin antibodies}

Microtubules have a defined polarity that determines the direction in which particular motors produce transport. Both dynein and kinesin are part of large family of closely related motor proteins that can move on microtubules. In general it is known that the motor protein family dynein moves toward the minus polarity of the microtubule, whereas the other motor protein family, kinesin, moves to the plus polarity although each family of motors has some subtypes that can move in the opposite direction (for review, see Vale, 1990; Vallee and Shpetner, 1990; Brady, 1991; Hirokawa et al., 1998). Because dendrites contain microtubules of both polarities (for review, see Baas, 1999), both dynein and kinesin could mediate transport from the soma to the dendrites.

To study the role of dynein family motors, we used an antibody against the dynein intermediate chain (Steuer et al., 1990), which interacts with vesicular cargoes via dynactin (Gill et al., 1991; Schroer and Sheetz, 1991; Paschal et al., 1992; Karki and Holzbaur, 1995; Vaughan and Vallee, 1995). This antibody blocks dynein function and has been used previously to study the role of dynein in several systems (Heald et al., 1996; Burkhardt et al., 1997). The antibody $(100 \mu \mathrm{g} / \mathrm{ml})$ was introduced into pyramidal cells by internal perfusion of the patch pipette, starting $20 \mathrm{~min}$ after the onset of whole-cell recording. Figure $1 \mathrm{~A}$, top, shows that the AMPA receptor component of synaptic transmission started to decline in amplitude after 10 min of antibody application and continued to decline over the next $2 \mathrm{hr}$. This gradual reduction is illustrated in the summary graph (Fig. $1 B$, top; $n=26$ ). During this period the input resistance of the cell was unaffected, indicating that the cell remained healthy throughout these long recordings (Fig. 1A,B, bottom). We accepted the results only if the series resistance remained low $(<15 \mathrm{M} \Omega)$, because in this range the fluctuations in series resistance do not change the size of the EPSC. Control antibodies or heat-inactivated anti-kinesin antibody (see below) did not produce any decrease during the first 80 min of perfusion (there even may be a very small early increase in the EPSC). After $80 \mathrm{~min}$ the control antibodies may have produced a small decrease in the EPSC by 10-20\%. Because the small decline after $2 \mathrm{hr}$ would have occurred even without the control antibodies, we did experiments without the control antibodies. The result showed that the decline of EPSC with the control antibodies after $2 \mathrm{hr}$ of whole-cell recording exactly matched the drift without any antibodies, suggesting that the control antibodies did not cause the decrease of EPSC after $2 \mathrm{hr}$ of recording. Comparing the effect of anti-dynein antibody with control antibody, we conclude that the anti-dynein antibody pro- 

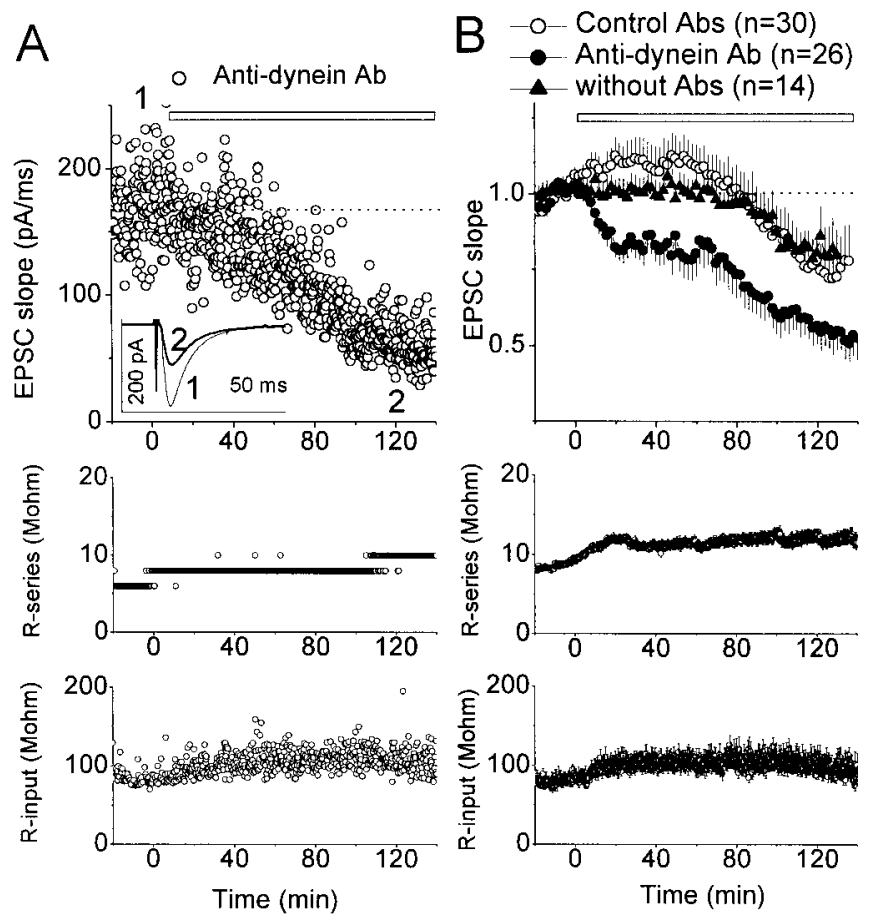

Figure 1. Effects of anti-dynein antibody on the AMPA receptormediated EPSC. The gray bar indicates the period of drug application. A, An example of postsynaptic application of anti-dynein antibody. The top plot shows the EPSC slope measurement. Inset, The average of 20 EPSC traces at given time periods. The numbers indicate the time periods before (1) and after (2) antibody application. The bottom two plots are the measurement of series resistance ( $R$-series) and input resistance ( $R$-input). $B$, Average effect of anti-dynein antibody. The top plot show the average effect of anti-dynein antibody on the AMPA receptor-mediated EPSC slope compared with that of control antibodies (total $n=30$; anti-gastric mucin antibody, $n=18$; anti-biotin antibody, $n=4$; anti-digoxin antibody, $n=8$; mean $\pm \mathrm{SE})$ and with that of no-antibody control $(n=14)$. The bottom two plots are the average measurement of R-series and R-input.

duced a $24.4 \pm 8.7 \%$ decrease (relative to control antibody) in the AMPA receptor-mediated EPSC after 130 min of application and that this effect was significant ( $p \ll 0.01$; Student's $t$ test).

To determine whether the anti-dynein antibody selectively affected the AMPA receptor component of transmission, we investigated the effect of the antibody on the isolated NMDA receptormediated EPSC. These measurements were carried at -60 or $-55 \mathrm{mV}$ holding potential; $5 \mu \mathrm{M}$ NBQX or $10 \mu \mathrm{M}$ CNQX was included in the aCSF to block the AMPA receptor-mediated EPSC. As shown in Figure 2, the NMDA receptor-mediated EPSC was not affected by anti-dynein antibody over a $2 \mathrm{hr}$ period.

To study the role of kinesin family motors, we used an antibody against bovine brain kinesin (clone IBII, Sigma). This antibody is known to bind to kinesin, and its ability to block motor function recently has been shown (Bananis et al., 2000). This antibody $(100 \mu \mathrm{g} / \mathrm{ml})$ produced a gradual reduction of the AMPA receptor-mediated EPSC. Figure $3 A$, top, shows that the AMPA receptor component of synaptic transmission started to decline in amplitude after $15 \mathrm{~min}$ of antibody application and continued to decline over the next hour. After $130 \mathrm{~min}$ this reduction was $\sim 34.6 \pm 6.8 \%$ relative to that of control antibodies (Fig. $3 B ; p \ll$ 0.1 ; Student's $t$ test). Heat-inactivated anti-kinesin antibody produced a similar effect on the AMPA receptor component with control antibodies, as expected (Fig. 3B). This decrease was
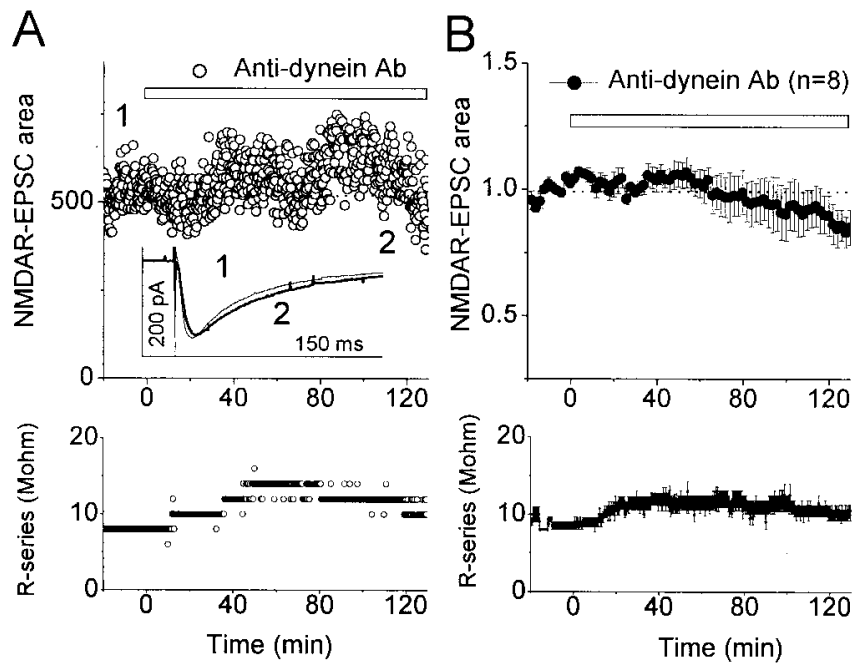

Figure 2. Lack of effects of anti-dynein antibody on the NMDA receptor-mediated EPSC. The gray bar indicates the period of drug application. $A$, An example of postsynaptic application of anti-dynein antibody. The top plot shows the EPSC area measurement. Inset, The average of 20 EPSC traces. The bottom plot is the measurement of R-series. $B$, Average effect of anti-dynein antibody application. The top plot shows the average effect of anti-dynein antibody on the area of the NMDA receptor-mediated EPSC. The bottom plot is the average measurement of R-series.

selective for the AMPA receptor component of EPSC; the NMDA receptor component was almost unaffected (Fig. 4).

We next determined how the response was affected by the combined application of kinesin and dynein motor inhibitors. If these motors worked on a common system or if the inhibition of one motor somehow blocked the action of the other, then adding both inhibitors should have no more effect than adding either alone. We found, however, that after a $130 \mathrm{~min}$ application the combination of inhibitors reduced EPSC by $50.3 \pm 10.0 \%$ (relative to control antibody, $n=8$; data not shown), a value almost twice that produced by each inhibitor alone. The simplest interpretation is that the dynein and kinesin motor processes are independent.

\section{Stable and labile components of the EPSC}

In the experiments with these antibodies we often noted in individual experiments that the decrease in the AMPA receptormediated response seemed to decline but then reached a plateau. Even in the average of all experiments (Figs. $1 B, 3 B$ ) that used antibodies to kinesin or dynein (or both; data not shown), there was little further decrease of the EPSC after $2 \mathrm{hr}$. However, data taken at such late times are problematic because of possible instabilities. Furthermore, it might be argued that the decrease would continue very slowly as more distal synapses on the dendrite progressively were affected. To determine whether a true plateau was reached, we believe it is necessary to have agents that decrease the AMPA receptor-mediated EPSC more rapidly. We therefore measured the kinetics of the decrease for a variety of drugs, alone or in combination, which decrease AMPA receptormediated transmission.

We first turned to study the action of a peptide that inhibits the interaction of the GluR2 C-terminal with NSF (Nishimune et al., 1998; Osten et al., 1998; Song et al., 1998). We found that the $\mathrm{NSF} / \mathrm{GluR} 2$ interaction inhibitory peptide (NSF/GluR2 ip) produced a large decrease in the AMPA receptor-mediated trans- 


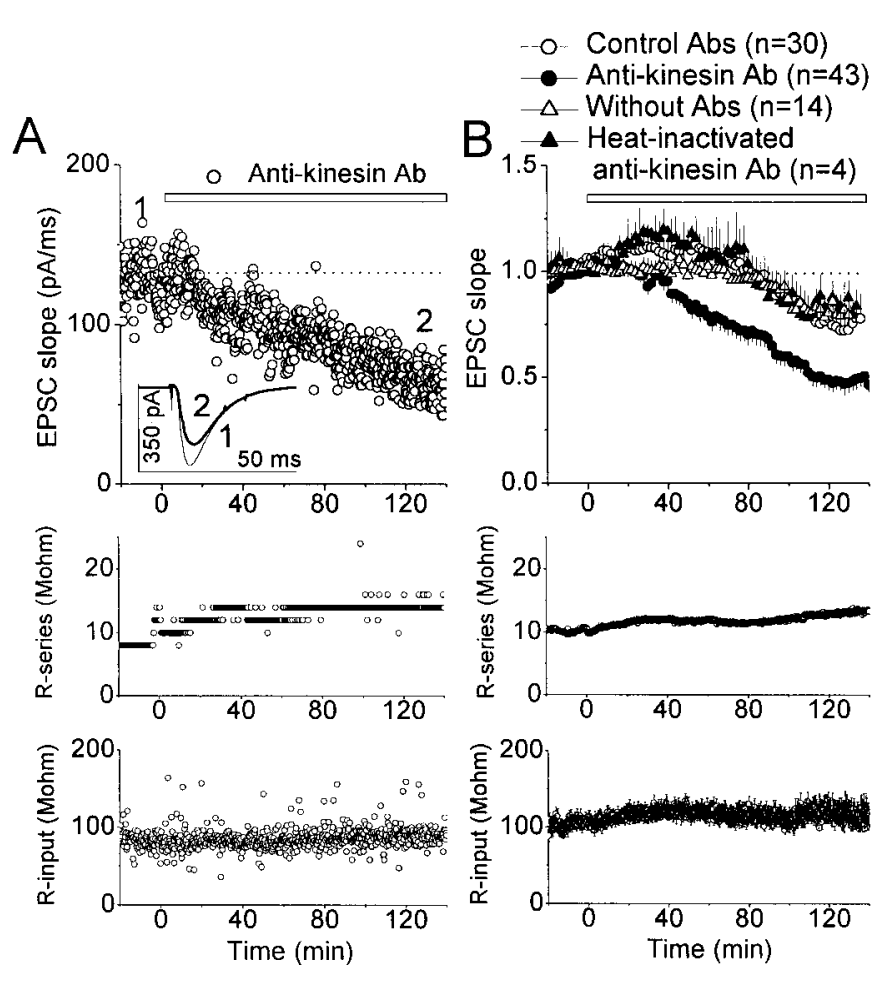

Figure 3. Effects of anti-kinesin antibody on the AMPA receptormediated EPSC. The gray bar indicates the period of drug application. $A$, An example of postsynaptic application of anti-kinesin antibody. The top plot shows the EPSC slope measurement. Inset, The average of 20 EPSC traces at the times indicated. The bottom two plots are the measurement of R-series and R-input. $B$, Average effect of anti-kinesin antibody application experiments. The top plot shows the average effect of anti-kinesin antibody $(n=43)$ on the AMPA receptor-mediated EPSC slope compared with that of control antibodies $(n=30$; mean $\pm \mathrm{SE})$, with that of heat-inactivated anti-kinesin antibody $(n=4$; mean $\pm \mathrm{SE})$, and with that of no-antibody control $(n=14)$, the latter two being replotted from Figure $1 B$ for comparison. The bottom two plots are the average measurement of R-series and R-input.

mission (Fig. $5 A$ ) with only minor effects on the NMDA receptormediated component (Fig. $5 C$ ), as reported previously (Noel et al., 1999). The minor effect on the NMDA receptor component produced by NSF/GluR2 ip $(13 \pm 6 \%$ decay at $80 \mathrm{~min}$ after postsynaptic application) is comparable with control experiments [14 \pm 5\%; Kim and Lisman (1999), their Fig. 7C], suggesting no significant effect of NSF/GluR2 ip itself on the NMDA receptor component. The inhibitory kinetics by NSF/GluR2 on AMPA receptor-mediated transmission is slower than we found previously for phalloidin (replotted here in Fig. 5A; Kim and Lisman, 1999), a substance that stabilizes actin filaments and inhibits their function. Figure $5 B$ shows one example experiment of the postsynaptic application of phalloidin alone. NSF/GluR2 ip alone reduced AMPA receptor-mediated transmission by $47.1 \pm 7.7 \%$ at 96 min of application (Fig. 5A), but it should be noted that it did not seem to reach a plateau. Phalloidin alone reduced EPSCs by $54.3 \pm 4.7 \%$ on average (Fig. $5 A$ ) and by $67 \%$ in one exemplary experiment (Fig. $5 B$ ) after $68 \mathrm{~min}$ of application. The example in Figure $5 B$ very clearly shows that a plateau effect was reached (total application time, $82 \mathrm{~min}$ ).

We next checked whether combining phalloidin and NSF/ GluR2 ip would produce a faster or stronger inhibition than phalloidin alone. Figure $5 A$ shows that after $1 \mathrm{hr}$ of perfusion of this combination there was $\sim 70 \%$ inhibition of the AMPA re-
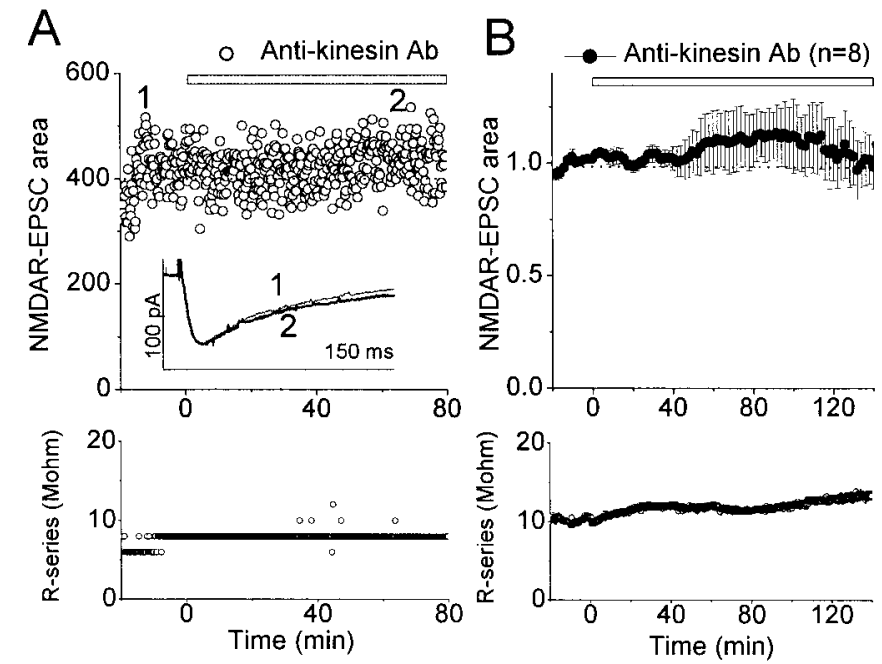

Figure 4. Lack of effects of anti-kinesin antibody on the NMDA receptor-mediated EPSC. The gray bar indicates the period of drug application. $A$, An example of postsynaptic application of anti-kinesin antibody. The top plot shows the EPSC area measurement. Inset, The average of 20 EPSC traces. The bottom plot is the R-series measurement. $B$, Average effect of anti-kinesin antibody. The top plot shows the average effect of anti-kinesin antibody on the area of the NMDA receptormediated EPSC. The bottom plot is the average R-series measurement.

ceptor component and that over the subsequent $2 \mathrm{hr}$ there was little or no further effect. Indeed, the data taken between 90 and 176 min after the start of perfusion show that the average responses could be fit by a horizontal line [the calculated slope is 0.4E-6 (normalized $\mathrm{pA} / \mathrm{min}$ ) and ANOVA $(F=1.311)$; a Student's $t$ test $(t=0.016)$ on the hypothesis that the slope is zero indicates that this is significant $(p>0.5)]$. These results thus show that a true plateau is reached and that there is component of AMPA receptor-mediated transmission that is not sensitive to $\mathrm{NSF} / \mathrm{GluR} 2$ ip and phalloidin. Figure $5 A$ also shows that the residual component $(32.6 \pm 3.9 \%)$ at $68 \mathrm{~min}$ after application of the combination was only slightly smaller than that produced by phalloidin alone (residual component $=45.3 \pm 7.0 \%$ ). The inhibition by NSF/GluR2 ip alone was $47.1 \pm 7.7 \%$ at $96 \mathrm{~min}$ of application, which was greater than those in previous studies [ 40\% in both Nishimune et al. (1998) and Luscher et al. (1999); $\sim 30 \%$ in Luthi et al. (1999)]. If the phalloidin and NSF/GluR2 ip effects were independent, the combination in our experiments should have inhibited the EPSC completely and left no residual component. What we found, however, is that a large residual component $(32.6 \pm 3.9 \%)$ remained. These results indicate that $\mathrm{NSF} / \mathrm{GluR} 2$ ip and phalloidin must affect the same component of AMPA receptor-mediated transmission. We further found that a combination of phalloidin and NSF/GluR2 ip had only minor $(\sim 10 \%)$ effects on the NMDA receptor-mediated EPSC after 80 min of application (Fig. $5 C$ ).

In a final series of experiments we checked whether the component of AMPA receptor-mediated transmission that is affected by these agents is also the component that is affected by the inhibitors of microtubule motors. To test this, we applied a combination of NSF/GluR2 ip and phalloidin and both microtubule motor inhibitors. If the antibodies would work on the pool of AMPA receptors that are not sensitive to NSF/GluR2 ip and phalloidin, we would see a larger inhibition by these all combined in one application. Figure 6 shows the result of the application of all four agents. In this experiment all four agents were included 

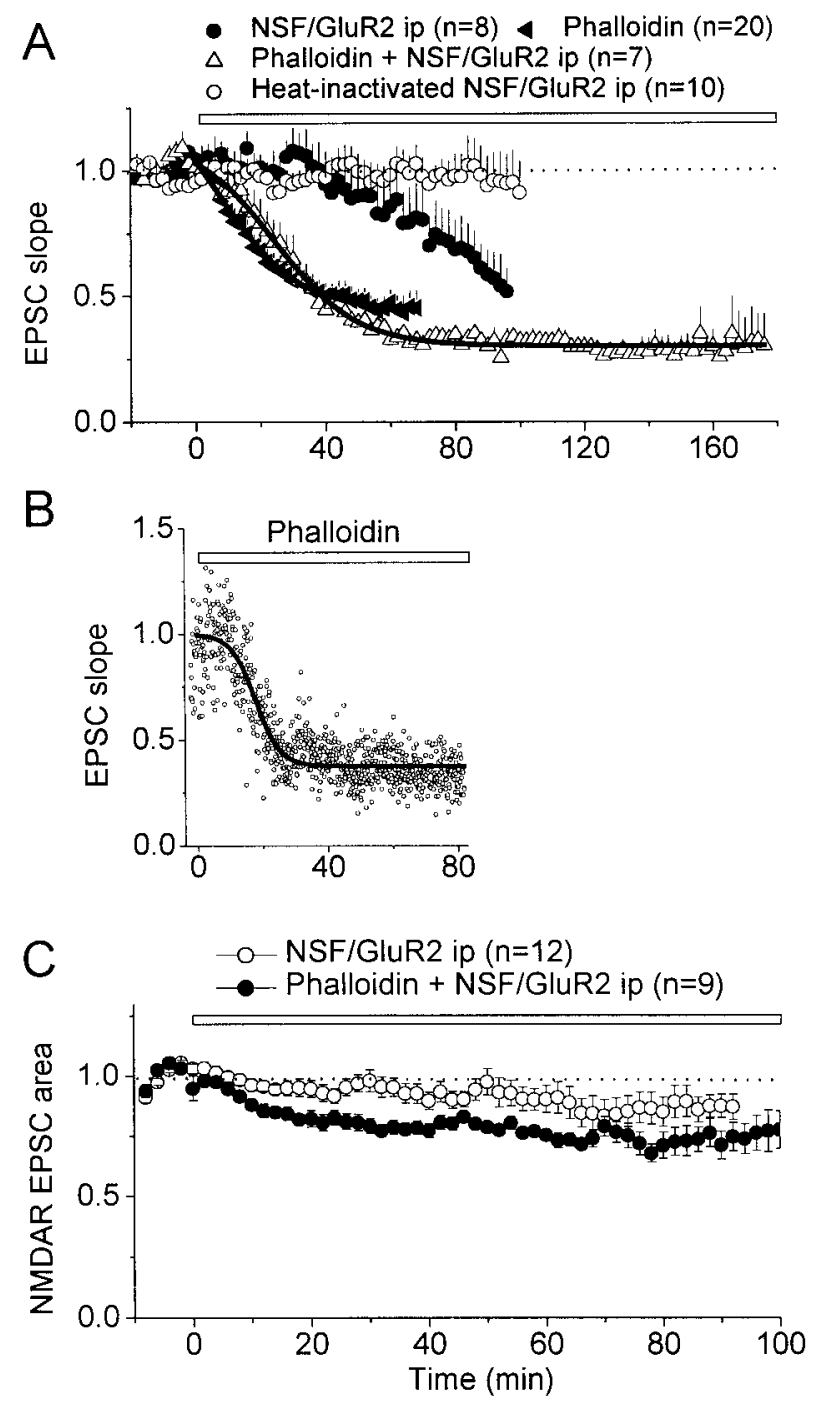

Figure 5. Effects of phalloidin and NSF/GluR2 ip on the AMPA receptor- and NMDA receptor-mediated EPSCs. The gray bar indicates the period of drug application. $A$, Effects of either phalloidin $(100 \mu \mathrm{M})$ alone, NSF/GluR2 ip (2 mM) alone, or a combination of both on the AMPA receptor-mediated EPSCs. As a control, heat-inactivated NSF/ GluR2 ip (2 mM) was used. The fitting curves (solid line) on the combination of phalloidin and NSF/GluR2 ip and on phalloidin alone are from sigmoidal curves [see Materials and Methods. Phalloidin alone, $\chi^{2} / \mathrm{df}=$ $2.633 \mathrm{E}-4 ; R^{2}$ (the coefficient of determination) $=0.99281 ; \mathrm{A} 2=44.9 \pm$ $0.8 \%$. Combination of NSF/GluR2 ip and phalloidin, $\chi^{2} / \mathrm{df}=5.661 \mathrm{E}-4$; $R^{2}=0.98832 ; \mathrm{A} 2=30.3 \pm 0.0 \%$ ]. $B$, A representative experiment of phalloidin $(100 \mu \mathrm{M})$ alone on the AMPA receptor-mediated EPSCs. The responses are normalized to the baseline. The solid line indicates a fitting curve, using a sigmoidal function $\left(\chi^{2} / \mathrm{df}=0.001207 ; R^{2}=0.80246 ; \mathrm{A} 2=\right.$ $37.7 \pm 0.0 \%)$. $C$, Effect of NSF/GluR2 ip $(2 \mathrm{mM})$ and phalloidin $(100 \mu \mathrm{M})$ on the NMDA receptor-mediated EPSCs.

directly in internal solution, and the responses were normalized to the average of the first 2 min responses. The inhibition was much faster than with each agent alone or with a combination of $\mathrm{NSF} / \mathrm{GluR} 2$ ip and phalloidin (at $50 \%$ of total inhibition, 10 vs 30 $\min )$. However, the residual component was $31.4 \pm 5.1 \%$ after $180 \mathrm{~min}$ of application, a value similar to that of NSF/GluR2 ip and phalloidin (Fig. $5 A$ ). These result shows that adding microtubule motor inhibitors affects the same component of AMPA receptor-mediated transmission as NSF/GluR2 ip and phalloidin.

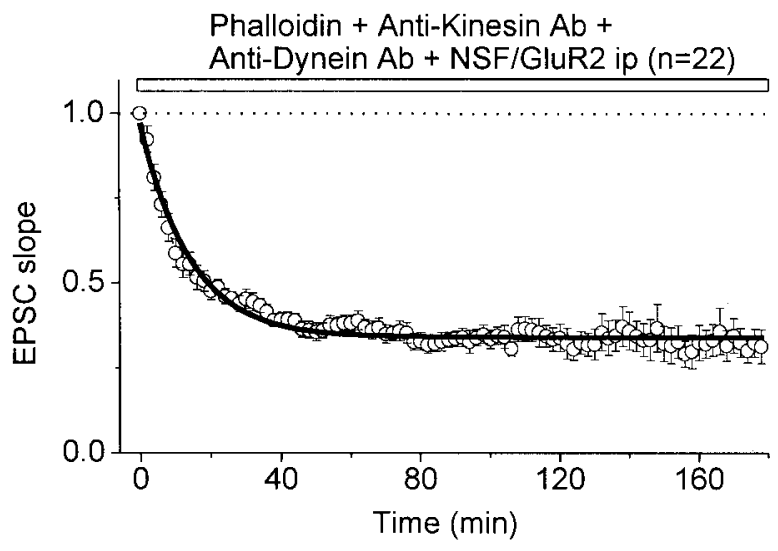

Figure 6. The effect of postsynaptic coapplication of microtubule motor inhibitors, actin filament inhibitors, and NSF/GluR2 interaction inhibitors on EPSCs. The gray bar indicates the period of drug application. Phalloidin $(100 \mu \mathrm{M}), \mathrm{NSF} / \mathrm{GluR} 2$ ip $(2 \mathrm{mM})$, anti-kinesin antibody $(100 \mathrm{gm} / \mathrm{ml})$, and anti-dynein antibody $(100 \mathrm{gm} / \mathrm{ml})$ were included in the patch pipette internal solution. The fitting curve (solid line) is from a sigmoidal curve $\left(\chi^{2} / \mathrm{df}=5.474 \mathrm{E}-4 ; R^{2}=0.96582 ; \mathrm{A} 2=34.1 \pm 0.0 \%\right)$.

\section{DISCUSSION}

Our results show that AMPA receptor-mediated EPSC is sensitive to inhibitors of the microtubule motors dynein or kinesin. The effect of inhibiting either motor protein occurred in $<1 \mathrm{hr}$ and was selective for the AMPA receptor component, producing little or no effect on the NMDA receptor EPSC and the resting membrane resistance. The effect was much larger than that produced by a variety of control antibodies having a similar structure. These results provide the first indication that the maintenance of basal synaptic transmission requires a microtubule motor process. The possibility that both dynein and kinesin are involved in the dendritic transport is consistent with the fact that microtubules of both orientations are present in dendrites. Our results show that, when both motor proteins were inhibited, the effect was approximately double that produced by each alone. This suggests that both motors systems operate independently to enhance AMPA receptor-mediated transmission.

The results we have found are consistent with the growing body of evidence that dynamic cellular processes are required to maintain AMPA receptor-mediated transmission on the time scale of hours, whereas NMDA receptor-mediated transmission is stable on this time scale. The selective vulnerability of the AMPA receptor-mediated response to inhibitory agents has been demonstrated previously for postsynaptically applied phalloidin, an inhibitor of actin filament (Kim and Lisman, 1999), and for postsynaptically applied NSF/GluR2 ip (Nishimune et al., 1998; Song et al., 1998; Luscher et al., 1999; Noel et al., 1999), a result we have replicated here (Fig. $5 A$ ).

A further conclusion of our study is that the dynamic process described above applies only to a component of the AMPA receptor-mediated response. We call this the labile component. Another component appears to be much more stable. Previous work (Nishimune et al., 1998; Luscher et al., 1999) showed that the effect of NSF/GluR2 ip on the AMPA receptor-mediated transmission was never complete and suggested that the residual component might have special properties. We have extended this work by measuring the decline of AMPA receptor-mediated transmission produced by several inhibitors and combinations of inhibitors (Figs. 5, 6). We found that the most rapid and extensive 
inhibition was produced by a combination of an actin filament inhibitor and an inhibitor of NSF/GluR2 interaction. This rapid action allowed us to establish firmly that, after the response was reduced to $30 \%$ of its initial value, there was no further effect in the subsequent $90 \mathrm{~min}$ (Fig. 5A,B). The stability and long duration of this plateau argue against a trivial explanation of the plateau, that the residual response is generated by a subset of synapses that happen to be located more distally.

Our examinations of inhibitors applied in combination lead us to conclude that the inhibitors are working on a common "labile" pool. Specifically, we found that the combination of NSF/GluR2 ip and phalloidin does not produce a substantially larger inhibition of the EPSP than phalloidin alone (Fig. 5B). Furthermore, if we add to this combination the inhibitors of both dynein and kinesin motors, no additional inhibition is observed. These occlusions indicate that there is a common component of AMPA receptor-mediated transmission that can be inhibited by all of these agents

Luthi et al. (1999) studied the relationship of LTD to the NSF/GluR2 ip-sensitive component. They showed that postsynaptically applied mouse NSF/GluR2 ip reduced transmission and that, in this condition, it was not possible to induce LTD. Conversely, if they first induced LTD, the response to NSF/GluR2 ip was not reduced. This mutual occlusion indicates a conclusion that LTD and NSF/GluR2 ip act on the same component of AMPA receptor-mediated transmission. Thus, what we term the labile pool appears to be the same pool on which LTD operates. However, it is noteworthy that the reduction that can be achieved by LTD $(\sim 40 \%)$ is smaller than the $70 \%$ reduction that characterizes the labile pool.

A reasonable working hypothesis that explains the various agents that can affect the labile pool is as follows: AMPA receptor channels are synthesized in the soma (Eshhar et al., 1993) and inserted into vesicles in the Golgi apparatus via processes that are standard for membrane proteins (Kelly and Grote, 1993). These vesicles then are transported into the dendrites by the microtubule motors of the dynein and kinesin families. The association of AMPA receptors with microtubules has been observed in neurons (Kessler and Baude, 1999). Importantly, very recent work shows directly that NMDA receptor channels are transported along dendritic microtubules by a motor that is a member of the kinesin family (Setou et al., 2000). When vesicles reach synapses in the dendrites, they may insert into the membrane by both a constitutive and an activity-dependent process, perhaps depending on AMPA receptor subtypes. At the same time endocytosis processes remove channels from the membrane (Lledo et al., 1998; Carroll et al., 1999a,b; Luscher et al., 1999; Man et al., 2000; Wang and Linden, 2000) (for review, see Luscher et al., 2000). While channels are in the membrane they can incorporate into the synapse and mediate transmission. We suspect that inhibiting microtubule motors inhibits AMPA receptor-mediated transmission simply because it blocks the supply of newly synthesized AMPA receptors. This transport presumably occurs in dendrites, where microtubules are abundant, but microtubule-dependent processes involving receptor transport or recycling also could be occurring in spines. NSF/GluR2 ip probably works by blocking the insertion or synaptic stabilization of the receptors in the cell membrane (Lledo et al., 1998; Nishimune et al., 1998; Song et al., 1998; Luscher et al., 1999; Noel et al., 1999; Man et al., 2000; Wang and Linden, 2000). There are several possible explanations for the effect of actin inhibitors, and these are not mutually exclusive. In many cell types the vesicles are transported to the near periphery on microtubules but then transfer from microtubules to actin filaments as they approach the membrane (Shelanski et al., 1981; Gavin, 1997; Depina and Langford, 1999; Huang et al., 1999; Goode et al., 2000). These dual mechanisms make sense for dendrites, because microtubules are found primarily in dendrites, whereas actin is found primarily in spines (Matus et al., 1982). Thus, to reach the spine synapses, vesicles containing AMPA channels might become dependent on actin-based motility. An activity-dependent process of delivery to spines has been visualized directly with GFP-labeled GluR1 (Shi et al., 1999), but it has not yet been determined whether this is actin-dependent. Another possible role of actin is to participate in the binding of AMPA channels to the postsynaptic density (Allison et al., 1998; Lisman and Zhabotinsky, 2001; Zhou et al., 2001).

Although it is possible to develop a reasonable picture of the labile pool, not much can be said about the nonlabile pool and why it is insensitive to disruption. An important first step will be to determine whether the labile and nonlabile components occur at the same synaptic sites or whether they reflect the properties of altogether different synapses, perhaps in a different state of maturity.

\section{REFERENCES}

Allison DW, Gelfand VI, Spector I, Craig AM (1998) Role of actin in anchoring postsynaptic receptors in cultured hippocampal neurons: differential attachment of NMDA versus AMPA receptors. J Neurosci 18:2423-2436.

Baas PW (1999) Microtubules and neuronal polarity: lessons from mitosis. Neuron 22:23-31.

Bananis E, Murray JW, Stockert RJ, Satir P, Wolkoff AW (2000) Microtubule and motor-dependent endocytic vesicle sorting in vitro. J Cell Biol 151:179-186.

Brady ST (1991) Molecular motors in the nervous system. Neuron 7:521-533.

Burkhardt JK (1998) The role of microtubule-based motor proteins in maintaining the structure and function of the Golgi complex. Biochim Biophys Acta 1404:113-126.

Burkhardt JK, Echeverri CJ, Nilsson T, Vallee RB (1997) Overexpression of the dynamitin (p50) subunit of the dynactin complex disrupts dynein-dependent maintenance of membrane organelle distribution. J Cell Biol 139:469-484.

Carroll RC, Beattie EC, Xia H, Luscher C, Altschuler Y, Nicoll RA, Malenka RC, von Zastrow M (1999a) Dynamin-dependent endocytosis of ionotropic glutamate receptors. Proc Natl Acad Sci USA 96:14112-14117.

Carroll RC, Lissin DV, von Zastrow M, Nicoll RA, Malenka RC (1999b) Rapid redistribution of glutamate receptors contributes to long-term depression in hippocampal cultures. Nat Neurosci 2:454-460.

Depina AS, Langford GM (1999) Vesicle transport: the role of actin filaments and myosin motors. Microsc Res Tech 47:93-106.

Eshhar N, Petralia RS, Winters CA, Niedzielski AS, Wenthold RJ (1993) The segregation and expression of glutamate receptor subunits in cultured hippocampal neurons. Neuroscience 57:943-964.

Gavin RH (1997) Microtubule-microfilament synergy in the cytoskeleton. Int Rev Cytol 173:207-242.

Gill SR, Schroer TA, Szilak I, Steuer ER, Sheetz MP, Cleveland DW (1991) Dynactin, a conserved, ubiquitously expressed component of an activator of vesicle motility mediated by cytoplasmic dynein. J Cell Biol 115:1639-1650.

Goldstein LSB, Yang Z (2000) Microtubule-based transport systems in neurons: the role of kinesins and dyneins. Annu Rev Neurosci 23:39-71.

Goode BL, Drubin D, Barnes G (2000) Functional cooperation between the microtubule and actin cytoskeletons. Curr Opin Cell Biol 12:63-71.

Hamm-Alvarez SF, Sheetz MP (1998) Microtubule-dependent vesicle transport: modulation of channel and transporter activity in liver and kidney. Physiol Rev 78:1109-1129.

Hayashi Y, Shi S-H, Esteban JA, Piccini A, Poncer J-C, Malinow R (2000) Driving AMPA receptors into synapses by LTP and CaMKII: requirement for GluR1 and PDZ domain interaction. Science 287:2262-2267.

Heald R, Tournebize R, Blank T, Sandaltzopoulos R, Becker P, Hyman A, Karsenti E (1996) Self-organizatioin of microtubules into bipolar spindles around artificial chromosomes in Xenopus egg extracts. Nature 382:420-425. 
Hirokawa N (1998) Kinesin and dynein superfamily proteins and the mechanism of organelle transport. Science 279:519-526.

Hirokawa N, Noda Y, Okada Y (1998) Kinesin and dynein superfamily proteins in organelle transport and cell division. Curr Opin Cell Biol 10:60-73

Huang JD, Brady ST, Richards BW, Stenolen D, Resau JH, Copeland NG, Jenkins NA (1999) Direct interaction of microtubule- and actinbased transport motors. Nature 397:267-270.

Karki S, Holzbaur ELF (1995) Affinity chromatography demonstrates a direct binding between cytoplasmic dynein and the dynactin complex. J Biol Chem 270:28806-28811.

Karki S, Holzbaur ELF (1999) Cytoplasmic dynein and dynactin in cell division and intracellular transport. Curr Opin Cell Biol 11:45-53.

Kelly RB, Grote E (1993) Protein targeting in the neuron. Annu Rev Neurosci 16:95-127.

Kessler JP, Baude A (1999) Distribution of AMPA receptor subunits GluR1-4 in the dorsal vagal complex of the rat: a light and electron microscope immunocytochemical study. Synapse 34:55-67.

Kim C-H, Lisman JE (1999) A role of actin filament in synaptic transmission and long-term potentiation. J Neurosci 19:4314-4324.

Kim JH, Huganir RL (1999) Organization and regulation of proteins at synapses. Curr Opin Cell Biol 11:248-254.

Kreitzer G, Marmorstein A, Okamoto P, Vallee R, Rodriguez-Boulan E (2000) Kinesin and dynamin are required for post-Golgi transport of a plasma-membrane protein. Nat Cell Biol 2:125-127.

Lippincott-Schwartz J (1998) Cytoskeletal proteins and Golgi dynamics. Curr Opin Cell Biol 10:52-59.

Lisman JE, Zhabotinsky AM (2001) A model of synaptic memory: a CaMKII/PP1 switch that potentiates transmission by organizing an AMPA-receptor anchoring assembly. Neuron, in press.

Lledo P-M, Zhang X, Sudhof TC, Malenka RC, Nicoll RA (1998) Postsynaptic membrane fusion and long-term potentiation. Science 279:399-403.

Luscher C, Xia H, Beattie EC, Carroll RC, Zastrow M, Malenka RC, Nicoll RA (1999) Role of AMPA receptor cycling in synaptic transmission and plasticity. Neuron 24:649-658.

Luscher C, Nicoll RA, Malenka RC, Muller D (2000) Synaptic plasticity and dynamic modulation of the postsynaptic membrane. Nat Neurosci 3:545-550

Luthi A, Chittajallu R, Duprat F, Palmer MJ, Benke TA, Kidd FL, Henley JM, Isaac JTR, Collingridge GL (1999) Hippocampal LTD expression involves a pool of AMPARs regulated by the NSF-GluR2 interaction. Neuron 24:389-399.

Maletic-Savatic M, Malinow R (1998) Calcium-evoked dendritic exocytosis in cultured hippocampal neurons. Part 1: trans-Golgi networkderived organelles undergo regulated exocytosis. $\mathrm{J}$ Neurosci 18:6803-6813

Man YH, Lin JW, Ju WH, Ahmadian G, Liu L, Becker LE, Sheng M, Wang YT (2000) Regulation of AMPA receptor-mediated synaptic transmission by clathrin-dependent receptor internalization. Neuron 25:649-662.

Matus A, Ackermann M, Pehling G, Byers HR, Fujiwara K (1982) High actin concentration in brain dendritic spines and postsynaptic densities. Proc Natl Acad Sci USA 79:7590-7594.

Nishimune A, Isaac JTR, Molnar E, Noel J, Nash R, Tagaya M, Col- lingridge GL, Nakanishi S, Henley JM (1998) NSF binding to GluR2 regulates synaptic transmission. Neuron 21:87-97.

Noel J, Ralph GS, Pickard L, Williams J, Molnar E, Uney JB, Collingridge GL, Henley JM (1999) Surface expression of AMPA receptors in hippocampal neurons is regulated by an NSF-dependent mechanism. Neuron 23:365-376.

Osten P, Srivastava S, Inman GJ, Vilim FS, Khatri L, Lee LM, States BA, Einheber S, Milner TA, Hanson PI, Ziff EB (1998) The AMPA receptor GluR2 C terminus can mediate a reversible, ATP-dependent interaction with NSF and alpha- and beta-SNAPs. Neuron 21:99-110.

Otmakhov N, Griffith LC, Lisman JE (1997) Postsynaptic inhibitors of calcium/calmodulin-dependent protein kinase type II block induction but not maintenance of pairing-induced long-term potentiation. J Neurosci 17:5357-5365.

Paschal BM, Mikami A, Pfister KK, Vallee RB (1992) Homology of the $74 \mathrm{kD}$ cytoplasmic dynein subunit with a flagellar dynein polypeptide suggests an intracellular targeting function. J Cell Biol 118:1133-1143.

Petralia RS (1997) Immunocytochemical localization of ionotropic glutamate receptors (GluRs) in neural circuits. In: The ionotropic glutamate receptors (Mohaghan DT, Wenthold RJ, eds), pp 219-263. Totowa, NJ: Humana.

Schroer TA, Sheetz MP (1991) Two activators of microtubule-based vesicle transport. J Cell Biol 115:1309-1318.

Setou M, Nakagawa T, Seog D, Hirokawa N (2000) Kinesin superfamily motor protein KIF17 and mLin-10 in NMDA receptor-containing vesicle transport. Science 288:1796-1802

Shelanski ML, Leterrier J-F, Liem RKH (1981) Evidence for interactions between neurofilaments and microtubules. Neurosci Res Program Bull 19:32-43

Shi S-H, Hayashi Y, Petralia RS, Zaman SH, Wenthold RJ, Svoboda K, Malinow R (1999) Rapid spine delivery and redistribution of AMPA receptors after synaptic NMDA receptor activation. Science 284:1811-1816.

Somogyi P, Tamas G, Lujan R, Bulh EH (1998) Salient features of synaptic organization in the cerebral cortex. Brain Res Rev 26:113-135.

Song I, Kamgoj S, Xia J, Dong H, Liao D, Huganir RL (1998) Interaction of the $N$-ethylmaleimide-sensitive factor with AMPA receptors. Neuron 21:393-400.

Steuer ER, Wordeman L, Schroer TA, Sheetz MP (1990) Localization of cytoplasmic dynein to mitotic spindles and kinetochores. Nature 345:266-288.

Turrigiano GG (2000) AMPA receptors unbound: membrane cycling and synaptic plasticity. Neuron 26:5-8.

Vale RD (1990) Microtubule-based motor proteins. Curr Opin Cell Biol 2:15-22.

Vallee RB, Shpetner HS (1990) Motor proteins of cytoplasmic microtubules. Annu Rev Biochem 59:909-932.

Vaughan KT, Vallee RB (1995) Cytoplasmic dynein binds dynactin through a direct interaction between the intermediate chains and p150Glued. J Cell Biol 131:1507-1516.

Wang YT, Linden DJ (2000) Expression of cerebellar long-term depression requires postsynaptic clathrin-mediated endocytosis. Neuron 25: $635-647$.

Zhon Q, Xiao M, Nicoll RA (2001) Contribution of cytoskeleton to the internalization of AMPA receptors. Proc Natl Acad Sci USA 98:12611266 . 